\title{
An Evaluation of the Psychological Factors influencing the Students' Anxiety in Speaking English
}

\author{
Elinda Umisara $^{1 凶}$, Abdurrachman Faridi $^{2}$, Henrikus Joko Yulianto ${ }^{2}$ \\ ${ }^{1 .}$ SMK karya Medika, Kabupaten Brebes, Indonesia \\ 2. Universitas Negeri Semarang, Indonesia
}

\begin{tabular}{l} 
Article Info \\
\hline Article History: \\
Recived 28 July 2021 \\
Accepted 3 October \\
2021 \\
Published 23 \\
December 2021 \\
\\
\hline Keywords: \\
Psychological Factor, \\
Foreign Language \\
Anxiety, and Speaking \\
Anxiety.
\end{tabular}

Keywords:

Foreign Language

Anxiety.

\begin{abstract}
Speaking is a productive skill that can be directly observed by considering several aspects. It can trigger the students' anxiety as a psychological factor to communicate foreign language with others. This case has become a unique phenomenon to be analysed because anxiety has a relevance with foreign language abilities. This study aims to evaluate the psychological factor influencing the students' anxiety in speaking English by using a qualitative approach. The data were collected by using observations, open-ended questionnaires, and interviews. There were 17 students in the ninth-grade of junior high school in Brebes Regency participating in this research. Three major phases of data analysis, namely data reduction, display, and conclusion drawing established to analyse the data. The researchers found three factors triggering the students' anxiety in speaking English, namely communication apprehension, test-anxiety, and fear of negative evaluation which were influenced by the situation-specific anxiety. The situation could represent an uncomfortable experience emotionally and physically for some students to speak English in the class. The students felt anxious, frustrated, fearful, nervous, worried when they were unable to speak English. It made the students afraid of making mistakes and like to underestimate their abilities so that this prevents them from doing verbal activities. Therefore, this research discusses ways to reduce the specific psychological factors that cause students' anxiety in speaking English. This result can be used as guidance in managing learning conditions, learning materials, and learning strategies to deal with students' anxiety in learning English. The teacher can use this research as a reference for analyzing the students' anxiety symptoms during learning English in order to increase the students' motivation and confidence in speaking performance.
\end{abstract}




\section{INTRODUCTION}

Learning English as an academic subject in Indonesia aims to make the students able to communicate verbally and nonverbally. In which, verbal communication transmits the messages through spoken language which encourages the speakers to be confident in conveying the information to the listener. Inability to convey spoken messages tends to trigger students' anxiety to speak the target language, especially in English. Horwitz et al. (1986) explain that anxiety is the students' psychological problem that affects students' courage in practicing the language being studied. It includes some feelings like tension, worry, and nervousness when speaking English in monologue or dialogue with the others.

Dörnyei (2005) explains that psychology deals with the human mind as a unique phenomenon of individual differences which are defined in a narrow sense as personality and intelligence. Dörnyei argues that psychology is established as a consistent predictor that can determine an individual's success or failure in learning foreign languages. According to Purba (2018), the psychological domain in learning a foreign language includes three main points. The first is language production. It is the process of creating and expressing messages through language. The second, language perception relates to an interpretation in understanding language. The third, language acquisition is related to how language is acquired. In this case, the students will master a language when they realize the importance of the learning process to fill the gaps of language knowledge (Schmidt, 2001 as cited in Lightbown \& Spada, 2013).

The students who feel anxious tend to withdraw from speaking activities as a form of negative anxiety reaction. It occurs because anxiety can make the students having difficulties understanding and conveying messages through spoken language (Horwitz et al., 1986). Dewi et al. (2020) claim that speaking skills are closely related to listening skills where the students must be able to distinguish sounds, understand vocabulary, grammar, and interpret information concurrently when doing interaction. Therefore, the success of learning speaking is not only influenced by cognitive but also effective aspects (Mahdalena \& Muslem, 2021).

As described in Oxford (1998) cited in Pratiwi and Analido (2018), the students' anxiety can be identified from the physiological symptoms and students' behavioural responses when the learner learns a foreign language. The psychological symptoms can be divided into three parts, namely general avoidance, physical action, and cultural dependent signs. Referring to the researchers' observations and the English teachers' statement, the researchers found the students' anxiety in learning English at junior high schools in Brebes Regency. There were several obstacles students faced in terms of speaking ability, such as their assumption that English was difficult in terms of understanding the word meaning, grammar, information, and pronunciation. The students' competency influences the cognitive and emotional process that occurs during the students learning English. The students' anxiety makes them like to underestimate themselves, due to feeling afraid, frustrated, shy, worried, and nervous to do the interaction in English classes. These things are classified as psychological problems that provoke students' anxiety.

Fitriah and Muna (2019) express the level of anxiety response into three general areas which evoke speaking anxiety. There are activity-tasks, speaking preparation, and language problems. Speaking activity is divided into micro and macro skills. It can affect students' anxiety levels related to the students' abilities. Speaking preparation is a way that can be used to reduce students' anxiety levels. It can increase the students' self-confidence to minimize speaking errors that may occur when students involve in speaking activities. Then language problems or errors have two points of view in terms of evaluation. A positive evaluation will increase students' self-confidence and reduce their anxiety, while a negative evaluation will have an impact on shyness which can increase the level of speaking anxiety. It has interconnected with Mustafa and Hasan (2013), 
the general speaking anxiety areas considered as the major factors of language anxiety, such as linguistics problem, cognitive challenge, and the teacher's role.

Moreover, there have been a number of studies concerning the psychological factors in speaking English that contribute to the learners' speaking skill. In the scope of psychological factors, there were some affective problems regarding the difficulties in conveying spoken messages, such as fear of making mistakes, shyness, anxiety, lack of confidence, and lack of motivation. Anxiety becomes one of the potential contributions of psychological problems in speaking English. It occurs because the students' assumptions about the lack of English abilities make them difficult to understand the language. Those cause the students' shyness, lack of self-confidence, and motivation to speak in English that become passive learners in English class (Arifin, 2017; Ariyanti, 2016; Jamila, 2014; Jannah \& Fitriati, 2016; Juhana, 2012; Sulastiani, 2020). In line with Brown (2007) anxiety is the most dominant factor that links to others' affective factors, such as self-esteem, self-efficiency, willingness to communicate, inhibition, risk-taking, empathy, and extroversion.

Regarding the previous studies, the main concern of this study is anxiety as one of the psychological factors which influence the students' anxiety in speaking. In which, the difficulty of learning English can make the students get less knowledge in the classroom. The fact that the students could not respond to the teacher's question in using English made most of the students reject the teacher's instruction because of anxiety. As stated by Sadighi and Dastpak (2017), speaking anxiety is positively correlated with refusal to establish a communication. Indrianty (2016) argues that students who feel anxious tend to have problems in understanding and responding to the oral instructions. This condition can decrease student motivation and self-confidence. Directly, those can give an impact on the development of the students' concept of learning a foreign language. It has been proven by the teacher in asking the students to do conversation and to answer the question related to the learning English activities.

This research aims to evaluate the psychological factor that influence the students' anxiety in speaking English. It becomes the reference as guidance to overcome the anxiety problems to speak English in the class. The result can refer to reduce the specific psychological factors which cause students' anxiety in speaking English. This research also becomes a crucial issue to study because it can be used by English teachers for implementing in the class. Later, it will be able to help the students to enjoy learning English with fun and helping to develop students' critical thinking, to select, and to sort appropriate information.

\section{METHODS}

This research uses qualitative case study to evaluate the psychological factors that influenced students' anxiety in speaking English from the students' point of view. The selection of case study was. based on the objectives to be achieved by the researchers. It is to evaluate the psychological factors influencing the students' anxiety in speaking English. Yin (2014) defined a qualitative case study as an approach where the researcher explores real life that involves multiple sources of information and reports it in the form of descriptions to maintain a holistic and real-world perspective.

This research is conducted by using a purposive sampling strategy by selecting the participants in the ninth-grade of junior high school in Brebes Regency, Central Java Province. There were 17 students selected as participants in this research. Purposive sampling using small sample was suitable to provide the relevant information regarding these research questions and goals (Fraenkel et al., 2012).

To avoid biasing the results of this research, the researchers used methodological triangulation to bridge the reliability and validity problems. The methodological triangulation emphasizes the researchers to use more than one 
method in gathering data (Fraenkel et al., 2012). Hence, the data analysis is carried out from the observation, open-ended questionnaire, and interview. The use of observation sheet was to report the students' condition, feeling, personal characteristics, and behavior in English classroom as it was adopted by Pratiwi and Analido (2018). The questionnaire is used to evaluate the students' anxiety of speaking English by giving open-ended questionnaires adopted by Horwitz et al. (1986). The interview guidelines are the questions lists which are used to evaluate and confirm students' responses to the questionnaire information adapted by $\mathrm{He}$ (2018). Three major phases of data analysis by Miles and Huberman (1994) were data reduction, display, and conclusion drawing. The data analysis was used to obtain the credibility, transferability, dependability, and confirmability data.

\section{RESULTS AND DISCUSSIONS}

In this section, the researchers presented the research results. It was found the indications that encouraged the students' anxiety in speaking. It brought forth the affective factors, such as fear of making mistakes, shyness, anxiety, lack of confidence, and lack of motivation. Those were contributed to the learners' communication skills so that the students were unable to convey the messages through spoken language. It affected the students' psychological states in terms of achieving their foreign language learning outcomes.

Scovel (1980) cited in Horwitz (2010) argued that speaking anxiety is categorized as situational-specific anxiety. Scovel asserts that this case can represent an uncomfortable experience emotionally and physically for some students in learning a foreign language. Taly and Paramasivam (2020) and Wardani (2018), argued that when the students feel worried about speaking English, they will show some observable symptoms of anxiety.
Referring to the findings, the researchers found that there were three signs of students' anxiety in speaking English: general avoidances, physical actions, and cultural dependence signs. The general avoidances experienced by students include forgetting to answer questions, being less prepared to learn English at school, and avoiding to use English. It made some students feel anxious during learning English so that they were unable to answer the question.

The physical actions were also giving signs indicating the students' anxiety. The characteristics of physical action experienced by students such as nervousness that makes students touch objects around them, play with their veil and clothes, and stutter in English. These occurred when the teacher asked the studenst to answer the question and come forward to present their task.

Afterwards, the cultural dependence signs influenced the students' apprehension which was characterized by the actions, such as avoiding interactions in class, reluctance to communicate and discuss, lack of eye contact when communicating, and excessive behavior such as smiling, laughing, and joking when feeling anxious. However, the students followed the actions because the students thought that English was not their own language and it was difficult.

These signs were influencing the students during learning English. It became the main indication that contributed to feeling apprehension in order to encourage the students' anxiety in speaking English. Feeling anxious attributed the students to the factors of anxiety such as communication apprehension, testanxiety, and fear of negative evaluation.

\section{Communication Apprehension}

According to Horwitz et al. (1986), communication apprehension concerns the students' ability to communicate with others in a foreign language. From this research, there were two cases that triggered the students' anxiety in learning speaking, namely lack of control over communicative situations and a lack of control over performance. Those cases play a large role 
in the foreign language learning process because it emphasizes interpersonal communication.

The case of lack of control over the communicative situation has a relationship with personal knowledge (Horwitz et al., 1986). As stated by Jannah and Fitriati (2016) the lack of speaking ability and limited knowledge of the language can make students become passive learners in the language class. Moreover, the findings also showed that there were nine students who experienced lack of control over the communicative situation. The students showed that they were feeling nervous, unconfident, shy, angry, afraid of being laughed at, and unable to understand.

Some problems appeared due to lack of a communicative situation, including being trembling when called upon in language class, uncomfortable in a foreign language class, having difficulty to concentrating, panic, and nervousness to talk in English. Those situations should be avoided because forcing students to speak English, such as calling students without letting them prepare for answers can make learning situations become scary for students (Arifin, 2017). He mentions that the learning condition can get traumatic for the students in the learning activities. Therefore, those problems indicate that the lack of control over the communicative situation makes the students become passive learners due to being anxious in speaking English.

Furthermore, the lack of control over performance occurs because the students have trouble speaking, which makes them shy to communicate with the others. The researchers argued that there were ten students who experienced this case. It made the students' performance always be supervised by others. It made students overthink due to their access to speak English. According to Mahripah (2014) in Ariyanti (2016), speaking skill requires interpersonal skill. The students who are not mastering speaking English will feel anxious since they have difficulty expressing their feelings and ideas in their performance. The problems arose in this case, namely having difficulty in understanding what the English teacher was saying, feeling nervous, and confused when they were speaking English. Those make the students have no strength to tackle their anxiety in speaking due to the problem of their performance. Referring to the argument of Arifin (2017), learning speaking does not only build the ability to produce verbal sentences well but also involves students' mental control as the basis in the speaking skill.

The result of this case showed that the feeling of shyness to communicate in English due to lack of control over communicative situations and performance were the aspects that underlie the communication apprehension in learning speaking. To ensure the factor of communication apprehension was to influence the students' anxiety in speaking English. The researchers did interview to follow up the result and found that the students were clearly afraid of making mistakes in speaking English. They asserted that making mistakes in speaking English could make them feel embarrassed due to being laughed by other students. This occurred because the students did not understand English well, being afraid to come forward, and being accustomed to using Javanese. Some of the students' statements, as follows; Biasa Jawa. Ia bu sama takut salah terus malu. (S03, QN.14) (Used daily Javanese. Yes ma'am, I was afraid of being mistaken and embarrassed) and Takut maju, malu diliatin, disurakin. (S10, QN.14) (Afraid to go forward, ashamed to be seen, and to be cheered on).

The factor of communication apprehension appeared as the consequence of speaking anxiety which influenced the students' self-control over speaking. The researchers gave another question to determine the students' feeling in speaking English. It analyzed the data of observation and questionnaire, the researchers found the students' anxiety in communication, such as difficulty to speak and to understand the information in order to feel anxious when communicating in English. This finding was supported by Horwitz et al. (1986), who say that foreign language learning derives from the personal knowledge that the students will have difficulty in understanding others and making 
oneself understood. The following excerpts were; $G a$ bikin takut tapi bikin bingung (S04, QN.15) (Not frightening, but confusing) and Iya takut salah (S07, QN.15) (Yes, afraid of making mistakes). Those indicated that the students had been frightened in communication when they realized their performance in speaking were insufficient. The students must speak English regularly, which would improve their speaking abilities. They were required to speak English in the language classroom rather than outside the class where they could speak their mother language.

Based on the fact, the students felt pressure in learning situations where their abilities seemed to be underestimated. It could make them feel shy to communicate in English. Regarding this phenomenon, the teacher also asserted that these are the problems faced by the students in speaking English. They did not only feel worried in speaking and writing in English. The teacher mentioned that the students had difficulties to differentiate the words in pronunciation and in writing form.

Communication apprehension was experienced by the students who had problems in communicative situations and performance due to lack of self-control. Exposed to the questionnaire and interview results, there were students who indicated speaking anxiety because of this factor. In the context of interpersonal communication, it was influenced by the students' anxiety in understanding the interlocutors. It could be seen from the students' obstacles that became the reasons to make the students' anxiety, such as difficulty in understanding English vocabularies that made them feel nervous, confused, unconfident, shy, angry, afraid of being laughed at, afraid to make mistakes, difficulties to differentiate the words, and unsatisfied about their performance.

The statements presented above show that some students did not like English and feel anxious when appointed by the teacher. Therefore, the difficulties experienced by the students had an impact on students' understanding of information from others and making oneself understand about the message. It gave the students little control with communicative situations and their performances in which they felt to be monitored.

\section{Test-anxiety}

This factor concerns the fear of being tested in every speaking activity. Horwitz et al. (1986) defined test-anxiety as the anxiety of performance that originates from the fear of failure and making a mistake. It made the students feel uncomfortable in the language class. The students who were anxious in speaking tests often assumed that their mistakes were a failure. This happens because this factor dominates the psychology of students in speaking English. Horwitz illustrates that the students who have high foreign language anxiety to do the oral test will experience a greater difficulty in speaking and make mistakes more often than students with low anxiety.

In the first case, the fear of failure exposed low levels of self-confidence which made students feel less competent with their abilities and their performances. This case is believed to trigger the low learning achievement and selfconfidence that appears in formal exam situations or other evaluative situations (Indrianty, 2016). Concerning finding, the researchers found seven students who reflected fear of failure in problems make students fearful that they would experience failure in speaking activities.

In the second case, fear of making an error appeared in a situation which made students anxious in the speaking test. The researchers found twelve students unconfident with their English competencies. They experienced excessive anxiety and fear of making mistakes in speaking English, especially in the tests and quizzes. Juhana (2012) asserts that the fear of making mistakes arises while the students feel conscious of their abilities in speaking English which makes the students get afraid of negative responses. This sign could be underlined for students avoiding the negative response due to making them feel safe when they could not get any negative response from the others. This condition made the students 
tend to avoid speaking English in the class, namely worrying about making mistakes, being fearful of being corrected, worrying about missing material, and nervousness when being asked a question. Furthermore, Jannah and Fitriati (2016) state that fear of making mistakes in the speaking test is a natural part of a foreign language learning process. In this case, encouraging students in a positive environment is needed to reduce the students' speaking testanxiety.

Based on the results of the open-ended questionnaire, the researchers verified the data to confirm the students' anxiety in the factor of communication apprehension by using interviews. The analysis showed that test-anxiety was influenced by fear of failure and fear of making errors. The data interview showed that the student was afraid and worried about making mistakes. It happened because they felt apprehensive about speaking English. However, the students could become afraid to fail to perform. It caused a lack of ability in speaking English. The following excerpts were: Takut kalau nilainya jelek. Karenakan masih belajar. (S07, QN. 17) (Afraid of getting a bad score. Because I was still learning) and Takut, ga percaya diri, terus di ketawain sama temen-temen. (S16, QN.17) (Afraid, unconfident, laughed at by friends). Their statements above were spoken by the students who were afraid of English. S07 showed that she was worried about getting a bad score. Meanwhile, S16 said that she was not only afraid of the speaking test, but she felt unconfident due to being laughed at by her friends.

The students who felt anxious in the speaking test would fail in their test. They felt nervous about the speaking test in front of class, it made them perform less due to being unmotivated and stressed. The teacher also gave the statement that most of the students were enthusiastic about speaking, but some other students did not want to become volunteers in speaking. According to Horwitz et al. (1986) test anxiety occurs when the students make mistakes and are fearful of failure in foreign language.
The researchers concluded that the test anxiety was the factor that influenced students' anxiety in learning speaking. The students revealed the reasons of speaking anxiety, namely feeling nervous, confused, insecure, shy, and uncomfortable speaking English in front of the class. These made the students think that learning speaking was difficult in order to make the students apathetic during learning activities. Test-anxiety had a greater impact on students' psychological, such as being fearful of being punished, tested, getting bad scores, being scolded by their parents, and not promoted to the next grade. Therefore, the reasons mentioned above made the students feel pressured and forced during speaking English.

\section{Fear of Negative Evaluation}

The factor of fear of negative evaluation is the wider scope in speaking anxiety because it occurs in many situations, such as social situations, speaking activities, and speaking tests (Horwitz et al., 1986). The researchers found three cases that affected students' anxiety in learning to speak English, namely apprehension about others' evaluation, avoidance of evaluative situations, and the expectation that others will evaluate oneself negatively.

Some of them are connected to oneself evaluation about linguistic aspects and sociocultural standards that make students uncover anxiety. Mulyani (2018) claims that linguistic difficulties such as difficulties in remembering vocabulary and applying the grammar rules of the target language are identified as linguistic problems that contribute to student anxiety. Meanwhile, the socio-cultural standard is related to the motivation for learning speaking which is obtained from the social environment. The students who feel anxious when speaking English will be sensible to be evaluated. They feel afraid of other evaluations as the real experience that makes the students avoid an evaluative situation and have imagined expectations that the others will evaluate their performance.

Feeling apprehensive about others' evaluation was shown by the students in 
speaking activities. The researchers found eight students who showed this emotional response. It was classified into the real evaluation experience in speaking English, especially negative evaluation that made the students anxious when encountering the same situation. Indrianty (2016) adds that the case is related to the problem of negative correction and evaluation which makes the students anxious. From this research, the students were feeling afraid to participate in speaking activities due to fear of getting negative responses. However, this case influenced the students' anxiety, such as feeling that other students were better at speaking English. Then, the students felt angry if they did not understand the teacher's correction.

In the second case, the students reflected avoidance of evaluative situations in speaking. The researchers found three students who were avoiding this thing. They avoided an evaluation because the fear of negative evaluation would occur again. In terms of speaking activities, anxiety occurs in situations when students are asked to speak in front of the class and their teachers (Indrianty, 2016). The existence of opinions about negative evaluations made some students more sensitive in the form of real and imaginary evaluations. They could try to avoid threatening situations. Hence, this case covered the problems, such as feeling embarrassed to be volunteers in answering the questions. It made them not want to take English class.

The third case of this factor is exposed to evaluate oneself negatively. The researchers found seven students who showed their anxiety because of having an imaginary evaluation. This case occurred because the students have negative thinking or negative evaluation based on their performance. It presented that the student thought other students were better than himself in speaking activity. That is related to negative prejudice in the form of bad images and judgments from others about their ability to carry out speaking activities in class (Ariyanti, 2016).

The open-ended questionnaire showed that fear of negative evaluation appeared as the factor that influenced students' anxiety in speaking English. Referring to the interview results, the researchers found that the students were not afraid of evaluating their speaking if the teacher gave the positive responses about the students' mistakes. It meant that the students could feel delighted when the teacher evaluated their speech in English and knew their mistakes. The following statements: Engga takut. Jadi seneng kalau dibenarkan. (S03, QN. 17) (Not afraid. So pleased if it was evaluated) and Kalo salah terus dibenerin ga takut bu. (S10, QN. 17) (If it was mistaken, it was corrected, not be afraid, ma'am).

Referring to the objective of this research, the reasons which made the students afraid of learning to speak English, was their fear of a negative evaluation by the teacher or other students. Negative evaluations, such as being laughed by others could make students insecure because they felt embarrassed. Related to the evaluation, the students gave some negative and positive responses. Based on the teacher's interview, she stated that the students' negative responses included-being lazy, easily giving up, and being ignorant in speaking English. Whereas, the teacher mentioned that the students would be pleased if they got a positive correction by the teacher.

To conclude, fear of negative evaluation appeared as the factor that influenced students' anxiety in speaking English. The data analysis above showed that the students felt unconfident in their English ability. It referred to the student's assumption that the other students were smarter, better, more diligent, more capable than themselves in speaking English. Those made the students feel nervous, afraid, and shy in speaking English, so they did not want to enter the English class due to avoiding the evaluation situations. Furthermore, the students asserted that they felt pleasant when being evaluated by the others. It had enabled them to know where they made mistakes in speaking English. However, they were afraid when they were getting negative evaluation by teachers or friends because it could decrease their motivation in learning speaking. 


\section{CONCLUSIONS}

Anxiety becomes the popular issue in learning English. It influences the students' development process as a psychological dimension which decreases the students motivation and confidence. The researchers did evaluate the factors emerging in this field. There were three signs of students' anxiety in speaking English, namely general avoidances, physical actions, and cultural dependence signs. These signs appeared during learning English which triggered the students' anxiety factors in speaking English, namely communication apprehension, test-anxiety, and fear of negative evaluation.

Communication apprehension concerns the students' ability to communicate with others in the target language which emphasizes interpersonal communication. This is influenced by two cases - lack of control over communicative situations and performance. It could be seen from the students' obstacles that have caused the students' anxiety, such as difficulty in understanding vocabularies, being afraid of being laughed, afraid of making mistakes, and unsatisfied with their performance.

The next factor is test-anxiety. It originates from the fear of failure and making a mistake that makes the students feel uncomfortable with experiences in the language class. It includes the fear of being tested in every learning activity. It made the students think that speaking was difficult in order to make the students apathetic during learning activities. Test-anxiety had an impact on students, namely fear of being punished, tested, getting bad scores, scolded, and not promoted to the next grade.

Then, fear of negative evaluation is the wider scope in speaking anxiety because it occurs in many situations, such as social situations, speaking activities, and speaking tests. It includes apprehension about others' evaluation, avoidance of evaluative situations, and the expectation that others will evaluate negatively. Those emerge because students are unable to convey their ideas through spoken language.

\section{REFERENCES}

Arifin, W. L. (2017). Psychological problems and challenges In EFL speaking classroom. Register Journal: Language \& Language Teaching Journals, 10(1), 29-47.

Ariyanti, A. (2016). Psychological factors affecting EFL students' speaking performance. ASIAN TEFL Journal of Language Teaching and Applied Linguistics, $1(1), 77-88$.

Brown, H. D. (2007). Principles of language learning and teaching (5th ed.). Longman.

Dewi, R., Rukmini, D., \& Mujiyanto, Y. (2020). Negative anxiety reduction through communicative English teaching material. International Journal of Innovation and Research in Educational Sciences, 7(3), 256-260.

Dörnyei, Z. (2005). The psychology of the language learner: Individual differences in second language acquisition. Lawrence Erlbaum Associates.

Fitriah, \& Muna, H. (2019). Foreign language speaking anxiety: A case study at English department students of IAIN Lhokseumawe and Al Muslim University. Jurnal Ilmiah DIDAKTIKA, 19(2), 140-158.

Fraenkel, J. R., Wallen, N. E., \& Hyun, H. H. (2012). How to design and evaluate research in education ( $8^{\text {th }}$ ed). Mc Graw Hill.

$\mathrm{He}, \mathrm{D}$. (2018). Foreign language learning anxiety in China. Springer.

Horwitz, E. K. (2010). Foreign and second language anxiety. Language Teaching, 43(2), 154-167.

Horwitz, E. K., Horwitz, M. B., \& Cope, J. (1986). Foreign language classroom anxiety. The Modern Language Journal, 70(2), 125-132.

Indrianty, S. (2016). Students' anxiety in speaking English (A case study in one hotel and tourism college in Bandung). Eltin, 4(1), 28-39. 
Jamila, M. (2014). Lack of confidence a psychological factor affecting spoken English of university level adult learners in Bangladesh. Language in India, 14(10), 156-168.

Jannah, M., \& Fitriati, S. W. (2016). Psychological problems faced by the year - eleven students of MA Nuhad Demak in speaking English. English Educational Journal, 6(1), 65-78.

Juhana. (2012). Psychological factors that hinder students from speaking in English class (A case study in a senior high school in South Tangerang, Banten, Indonesia). Journal of Education and Practice, 3(12), 100-110.

Lightbown, P. M., \& Spada, N. (2013). How languages are learned ( $\left.4^{\text {th }} \mathrm{ed}\right)$. Oxford University Press.

Mahdalena, \& Muslem, A. (2021). An analysis on factors that influence students' anxiety in speaking English. Research in English and Education, 6(1), 9-22.

Miles, M. B., \& Huberman, A. M. (1994). An expanded sourcebook qualitative data analysis. Sage Publications.

Mulyani, S. (2018). Investigating factors causing students' anxiety in speaking English. International Journal of Applied Linguistics of Parahikma, 1(1), 85-99.

Mustafa, N \& Hasan, S. (2013). Students' perception of language anxiety in speaking class. Journal of History Culture and Art Research, 2(2), 142-160.

Pratiwi, M. A., \& Analido, B. (2018). EFL Students' anxiety in research proposal seminar. Proceedings of the Sixth International Conference on English Language and Teaching, 6(6), 184-194.

Purba, N. (2018). The role of psycholinguistics in language learning and teaching. Teaching of English Language and Literature Journal, 6(1), 47-54.

Sadighi, F., \& Dastpak, M. (2017). The sources of foreign language speaking anxiety of Iranian English language learners. International Journal of Education and Literacy Studies, 5(4), 11-23.

Sulastiani. (2020). Students' perception toward psychological problems faced in public speaking class. Journal La Edusci, 1(1), 3339.

Taly, B. C., \& Paramasivam, S. (2020). Speaking anxiety among Postgraduate International Students in the academic context of a University in Malaysia. International Journal of Linguistics, 12(1), 198-219.

Wardani, W. K. (2018). The characteristics of anxious students in speaking class. Journal of Foreign Language Teaching and Learning, $3(2), 60-73$.

Yin, R. K. (2014). Case study research: Designs and methods. Canadian Journal of Program Evaluation, 30(1), $1-5$. 